\title{
Qualitative Research in Applied Linguistics: A Practical Introduction, edited by Juanita Heigham and Robert Croker
}

\author{
Kamran Akhtar Siddiqui', Bahawal Soomro², Rashid Hussain Abbasi ${ }^{3}$, \\ Usama Abdul Rehman ${ }^{4}$, Aizaz Soomro ${ }^{5}$ \\ 1,2,3,4 Sukkur IBA University, Airport Road, Sukkur, Pakistan \\ 5 IBA Community College, Khairpur, Pakistan
}

\begin{tabular}{|c|c|}
\hline (A) Check for updates open 0 access cc) (i) (2) & DOI : https://doi.org/10.46245/ijorer.v2i5.110 \\
\hline Sections Info & ABSTRACT \\
\hline Article history: & This review makes a point in favor of the assertion made for the book that it is \\
\hline Submitted: March 27, 2021 & a practical introduction to the qualitative research in applied linguistics. The \\
\hline Final Revised: August 6, 2021 & book consists of four parts: an overview of qualitative research, qualitative \\
\hline Accepted: September 11, 2021 & research methods, qualitative data collection methods, ethical practice issues \\
\hline Published: September 30, 2021 & and the writing of research reports. After proving a rich introduction to the \\
\hline Keywords: & qualitative research, the book discusses qualitative research approaches using \\
\hline Qualitative & a reader-friendly and interactive structure: pre-reading and post-reading \\
\hline Ressearch & questions along with the list of further readings. Then the data collection tools \\
\hline Methods & have been thoroughly discussed. What makes this book more useful is the use \\
\hline Data Collection & of illustrative examples for each qualitative research approach and data \\
\hline Applied Linguistics & collection tool. The last part discusses core issues of ethics and drafting a \\
\hline 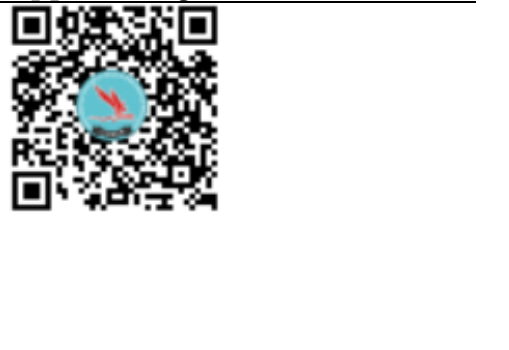 & $\begin{array}{l}\text { research report. From the perspective of a novice researcher, it has achieved } \\
\text { the goal of educating readers about qualitative research methods and data } \\
\text { collection tools, as it gradually tracks the reader and provides them with a } \\
\text { linking concept for a better understanding. However, reference to one study } \\
\text { for both ethnography and case study remains a confusing point. Besides, the } \\
\text { review suggests addition of some images to make reading of the book more } \\
\text { interesting, especially for visual learners. Besides, a diagram should be given } \\
\text { at the end of research methods chapters to outline the steps taken by } \\
\text { researchers to do their studies. }\end{array}$ \\
\hline
\end{tabular}

Research is a difficult task for teachers engaged in practical activities because it involves a great deal of time and effort. And given their long teaching hours, they are unable to provide both. However, it is essential to enter the field of research because research is critical to the personal and professional growth of academicians. One of the problems faced by most teachers and novice researchers in this regard is clear understanding of basic research concepts and methods. The Qualitative Research in Applied Linguistics: An Introduction to Practice, edited by Juanita Heigham and Robert Croker, is a practical guide with interactive activities for all such researchers, who hope to obtain feasible qualitative research ideas, especially in the field of linguistics. The book mainly aims to to inform the reader of the main qualitative research methods and develop data collection skills among them.

This book is divided into four parts: an overview of qualitative research, qualitative research methods, qualitative data collection methods, ethical practice issues and the writing of research reports. Easy to difficult approach adopted in the chapters and easyto-understand English makes it very convenient for the general reader. Each chapter discusses an idea and tries to discuss it as a whole. In addition, each chapter begins with a list of pre-reading questions and then discusses the topic extensively 
Qualitative Research in Applied Linguistics: A Practical Introduction, edited by Juanita Heigham and Robert Croker

supported by the existing literature, and concludes with not only a summary of the chapter but also post-reading questions, tasks and a list of further readings. The topicrelated charts, easy-to-read boxes and bullet points also help to understand the content.

The book begins with an overview of the qualitative studies by Robert Croker and Donald Freeman. Croker (2009) defines qualitative research as "an umbrella term used to refer to a complex and evolving research methodology" having roots in various disciplines (p. 05). The initial chapters stresses upon the idea that qualitative research aims to have a comprehensive and rich understanding of the research environment. So, what makes a study qualitative is an in-depth inquiry into the question, person, or background. This painstaking examination of the story provides the basis for the researchers' argument.

The second part of the book is the most important because it discusses qualitative methods. Although the chapters in this section follow the same reader-friendly and interactive structure, what makes them more useful is the use of illustrative examples. For example, in his history of narrative exploration, Garold Murray illustrates his own experience of collecting the life history of learners. Similarly, Michael Hood's chapter on case studies illustrates a teacher who wonders why so many ESL students are unable to complete their college education despite successfully completing the preparation intensive English course.

The ethnographic chapter written by Juanita Heigham and Keiko Sakui revolves around Elizabeth, an English as a Foreign Language (EFL) teacher's question of why a strong community of learners develops at self-access center (SAC) at one time and does not develop at the other time despite standardized freshman orientation about SAC. Similarly, in the chapter "Action Research," Anne Burns talks about an Indonesian teacher trying to understand the student interactions in her English communication class. In the last chapter on Mixed Methods, written by Natalia Ivankova and John Creswell, uses an illustrative example of Li Jie and Qin Xiaoqing who are foreign language education researchers in China and are interested to study the relationship between student learning style and learning strategy to English language learning success. To understand the differences in learning strategies between advanced learners and lower learners, the researchers first collected quantitative data from many learners, but then focused on only three of each group of learners for the purpose of their study.

The third part discusses qualitative data collection methods, such as observation, interviews, open questionnaires, oral reports, journal studies and discourse analysis. Neil Cowie's "Observations" chapter and Keith Richard's "Interview" chapter provide useful insights into the tool's preparation, use, and interpretation of the data collected through it, and reporting findings. Richard, in his chapter on interviews, specifically cites Wooffitt and Widdicombe (2006) to show how the location of researchers and respondents affects the importance of what is said and explained. In addition, James Dean Brown and Sandra Lee McKay discuss the "Open Response Project" in Questionnaires and Introspection Techniques in subsequent chapters. James Dean Brown tells the story of Kazuko, who investigates "knowing her colleagues to think in their own way" (p. 201). McKay points out that these tools provide evidence of the psychological processes of learners and teachers, thus demonstrating the use of oral reports and journalism studies. In the final chapter of this section, Anna Lazaraton's "Discourse Analysis" illustrates a study of student repair events, as detailed 
Qualitative Research in Applied Linguistics: A Practical Introduction, edited by Juanita Heigham and Robert Croker

transcriptions helped the illustrative teacher Ellen to see the miscommunication points in the speech of her students and how to repair them. However, some argue that discourse analysis is not only a method of data collection, but also a method (Salkind, 2010).

The final section focuses on the key issues behind each study, such as ethics and writing research. Chapters on Ethical Issues by Sharon Rallis and Gretchen Rossman, as well as research by Christine Casanave, are important because they contribute to research. Without the study of ethics, we cannot truly reveal reality.

If the book is analyzed from the perspective of a novice researcher, it has achieved the goal of educating readers about qualitative research methods and data collection tools, as it gradually tracks the reader and provides them with a linking concept for a better understanding. In this regard, Garold Murray's explanation of his research is crucial, as he discusses all the steps he has taken. In addition, further reading list also guides the reader in obtaining detailed knowledge of the topic and research methods without wasting any time in search of finding reliable resources for the discussed topics. One slightly confusing thing about the book for novice researchers, however, is the reference to Heath (1983)'s long-running study Way With Words as a "must-read for anyone interested in both ethnography and case study" (p. 84). For the sake of improvement of the book, it is suggested that some images should be included to make reading of the book more interesting, especially for visual learners. Besides, a diagram should be given at the end of research methods chapters to outline the steps taken by researchers to do their studies. This will work as the summary of the illustrative case.

In short, this book Qualitative Research in Applied Linguistics: An Introduction to Practice, edited by Juanita Heigham and Robert Croker is an excellent resource for research students and teachers alike. It develops step by step understanding of the research concepts, provides interactive reading activities, and offers a rich list for further readings for better understanding of methods and tools. However, the book slightly shies away from sharing the exact data collection tools used in actual and/or illustrative studies. Despite this, this is indeed a must read book for all researchers, particularly novice ones.

\section{REFERENCES}

Croker R.A. (2009). An introduction to qualitative research. In Heigham J., Croker R.A. (eds) Qualitative research in applied linguistics. Palgrave Macmillan, London. https://doi.org/10.1057/9780230239517_1

Heath, S. B. (1983). Ways with words: Language, life and work in communities and classrooms. Cambridge university Press.

Salkind, N. J. (2010). Encyclopaedia of research design: Discourse analysis. SAGE Publications. https://dx.doi.org/10.4135/9781412961288.n115

Wooffitt, R., \& Widdicombe, S. (2006). Interaction in interviews. In P. Drew, G. Raymond, \& D. Weinberg (Eds.), Talk and interaction in social research methods (pp. 28-49). Sage Publications Ltd. https://doi.org/10.4135/9781849209991.n3 
Qualitative Research in Applied Linguistics: A Practical Introduction, edited by Juanita Heigham and Robert Croker

*Kamran Akhtar Siddiqui (Corresponding Author)

Department of Maths and Social Sciences

Sukkur IBA University,

Airport Road, Sukkur 65200, Pakistan

Email: Kamran.akhtar@iba-suk.edu.pk

\section{Bahawal Soomro}

Department of Maths and Social Sciences

Sukkur IBA University,

Airport Road, Sukkur 65200, Pakistan

Email: Bahawal.soomro@iba-suk.edu.pk

\section{Rashid Hussain Abbasi}

Department of Maths and Social Sciences

Sukkur IBA University,

Airport Road, Sukkur 65200, Pakistan

Email: rashidhussain@iba-suk.edu.pk

\section{Usama Abdul Rehman}

Department of Maths and Social Sciences

Sukkur IBA University,

Airport Road, Sukkur 65200, Pakistan

Email: usamaabdulrehman@iba-suk.edu.pk

\section{Aizaz Soomro}

IBA Community College Khairpur

Sukkur IBA University,

Airport Road, Sukkur 65200, Pakistan

Email: aizaz.aijaz@yahoo.com 